www.jmscr.igmpublication.org

Index Copernicus Value: 79.54

ISSN (e)-2347-176x ISSN (p) 2455-0450

crossref DOI: https://dx.doi.org/10.18535/jmscr/v7i6.27

\title{
A Study of Phosphorus Levels as a Prognostic Indicator in Diabetic Ketoacidosis
}

\author{
Authors \\ Vijaya Kumar Rajendran ${ }^{1}$, Dhananjayan Kannan ${ }^{2 *}$ \\ ${ }^{1}$ Assistant Professor, ${ }^{2}$ Senior Assistant Professor \\ Department of General Medicine, Government Kilpauk Medical College and Hospital, Chennai 600010 \\ *Corresponding Author \\ Dhananjayan Kannan \\ Senior Assistant Professor, Department of General Medicine, Government Kilpauk Medical College and \\ Hospital, Chennai 600010, India
}

\begin{abstract}
Background: Diabetic ketoacidosis is an emergency complication of Diabetes Mellitus ${ }^{[1]}$. Phosphate depletion is common in DKA. This study was undertaken to find out mainly the use of serum phosphorus in Diabetic ketoacidosis as a prognostic indicator to assess the mortality and morbidity and determine the outcome.
\end{abstract}

Materials and Methods: 50 consecutive diabetic patients presenting with clinical and biochemical features of DKA admitted to IMCU Thanjavur Medical college hospital from January to August 2014 were studied.

Results: The study shows phosphorus levels at the time of admission can be used as a prognostic indicator in Diabetic Ketoacidosis.

Conclusion: High blood sugar is associated with a low phosphate value. Low serum phosphate was associated with a poor mental status and prolonged hospital stay.

Keywords: Acidosis, chi-square test, hyperglycemia, ketoacidosis, phosphorus.

\section{Background}

Diabetic ketoacidosis is an acute complication of diabetes. Diabetic ketoacidosis is characterised by hyperglycemia, ketonemia (ketonuria), metabolic acidosis (high anion gap) along with a number of metabolic derangements. It is more common in women from low socio-economic group. It mainly affects type 1 diabetes patients. Among $4 \%$ of all patients with diabetes, $20 \%$ of those with type 1 diabetes were admitted in hospital with manifestations of diabetes. Diabetic ketoacidosis is often precipitated by intercurrent illness such as infection, inadequate insulin administration by the patient. Commonest presenting complaints were nausea, vomiting, polydipsia, polyuria, abdominal pain and altered sensorium. Parameters related to mortality include duration of prior diabetes, severity of acidosis, severity of peripheral vascular insufficiency and comorbid conditions. The study was therefore undertaken to find out mainly the use of serum phosphorus in Diabetic ketoacidosis as prognostic indicator to assess the mortality and morbidity and determine the outcome. Phosphate depletion is common in 
DKA. But the initial value may be high, normal or low. Hypophosphatemia will result in decreased 2,3-diphosphoglycerate in erythrocytes.

\section{Materials and Methods}

\section{Source of Data}

50 consecutive diabetic patients presenting with clinical and biochemical features of DKA admitted to IMCU Thanjavur Medical College Hospital from January to August 2014 were studied.

\section{Sample Size}

Size of the sample, $\mathrm{n}=50$

\section{Inclusion Criteria}

Patients admitted in IMCU/ICCU

1) All DKA patients who met clinical and biochemical features.

2) Both type 1 and 2 diabetes.

\section{Exclusion Criteria}

1) Patients treated with phosphate binding drugs

2) Patients receiving phosphate supplements.

\section{Collection of Data}

Random blood glucose sample was measured at the time of admission. It is estimated by glucose oxidase glucose peroxidase technique.
Serum Inorganic Phosphate ${ }^{[2]}$

Levels were measured by FISKE-SUBBA ROW method.

\section{Patient Stratification}

Patients were grouped into 2 categories according to their admission serum phosphorus levels,

Group 1: serum phosphorus $<2.5 \mathrm{mg} \%$

Group 2: serum phosphorus $>2.5 \mathrm{mg} \%$

\section{Study of End Points}

The primary endpoint of this study is duration of stay in the hospital.

\section{Statistical Methods}

Data was analysed by using the following methods:

1. Diagrammatic representation

2. Mean $+\mathrm{SD}$

3. Chi square test for non-continuous variables

4. Analysis of variance for continuous variables

5. Multivariate analysis tests to determine the association between serum phosphorus and hospital stay.

\section{Comparison of Admission RBS Value with Serum Phosphorus}

\begin{tabular}{|l|c|c|c|c|}
\hline $\begin{array}{l}\text { ADMISSION } \\
\text { RBS }\end{array}$ & $\begin{array}{c}\text { PHOSPHORUS } \\
<2.5 \mathrm{mEq} / \mathrm{L}\end{array}$ & $\begin{array}{c}\text { PHOSPHORUS } \\
2.5 \mathrm{mEq} / \mathrm{L}\end{array}$ & $\begin{array}{c}\text { PHOSPHORUS } \\
>2.5 \mathrm{mEq} / \mathrm{L}\end{array}$ & $\begin{array}{c}\text { STATISTICAL } \\
\text { SIGNIFICANCE }\end{array}$ \\
\hline 200 to 300 & 0 & $2(6.3 \%)$ & $2(6.4 \%)$ & $\begin{array}{c}\text { Significant } \\
\mathrm{p}<0.05\end{array}$ \\
\hline 301 to 400 & $5(27.8 \%)$ & $25(78.1 \%)$ & $30(60 \%)$ & $\begin{array}{c}\text { Significant } \\
\mathrm{p}<0.05\end{array}$ \\
\hline 401 to 500 & $13(72.2 \%)$ & $5(15.6 \%)$ & $18(36 \%)$ & $\begin{array}{c}\text { Significant } \\
\mathrm{p}<0.05\end{array}$ \\
\hline
\end{tabular}

There is a statistically significant association between serum phosphorus level at the time of admission and initial blood sugar value of DKA patients.

It is proven by Chi Square test. 


\section{Chart Title}

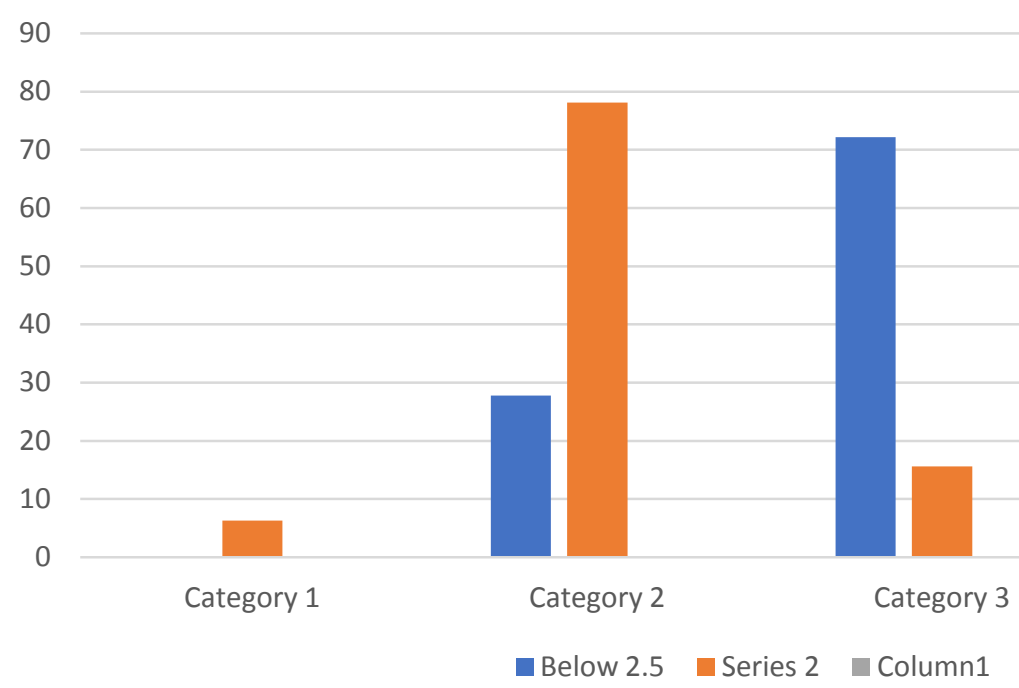

\section{Comparison of Duration of Hospital Stay with Phosphorus Levels}

\begin{tabular}{|c|c|c|c|c|}
\hline $\begin{array}{lr}\text { DURATION } & \text { OF } \\
\text { HOSPITAL } & \text { STAY } \\
\text { IN DAYS } & \end{array}$ & $\begin{array}{c}\text { PHOSPHORUS } \\
<2.5 \mathrm{mEq} / \mathrm{L}\end{array}$ & $\begin{array}{c}\text { PHOSPHORUS } \\
<2.5 \mathrm{mEq} / \mathrm{L}\end{array}$ & $\begin{array}{c}\text { PHOSPHORUS } \\
>2.5 \mathrm{mEq} / \mathrm{L}\end{array}$ & $\begin{array}{l}\text { STATISTICAL } \\
\text { SIGNIFICANCE }\end{array}$ \\
\hline 2 & $2(11.1 \%)$ & $9(28.1 \%)$ & $11(22 \%)$ & $\begin{array}{c}\text { Significant } \\
\mathrm{p}<0.05\end{array}$ \\
\hline 3 & $1(5.6 \%)$ & $19(59.4 \%)$ & $20(40 \%)$ & $\begin{array}{c}\text { Significant } \\
\mathrm{p}<0.05\end{array}$ \\
\hline 4 & $2(11.1 \%)$ & $3(9.4 \%)$ & $5(10 \%)$ & $\begin{array}{l}\text { Significant } \\
\mathrm{p}<0.05\end{array}$ \\
\hline 5 & $9(50 \%)$ & $1(3.1 \%)$ & $10(20 \%)$ & $\begin{array}{l}\text { Significant } \\
\mathrm{p}<0.05\end{array}$ \\
\hline 6 & $4(22.2 \%)$ & 0 & $4(8 \%)$ & $\begin{array}{c}\text { Significant } \\
\mathrm{p}<0.05\end{array}$ \\
\hline
\end{tabular}

There is a statistically significant association between duration of hospital stay and serum phosphorus levels at the time of admission in DKA patients.

It is proven by Chi Square test.

\section{Chart Title}

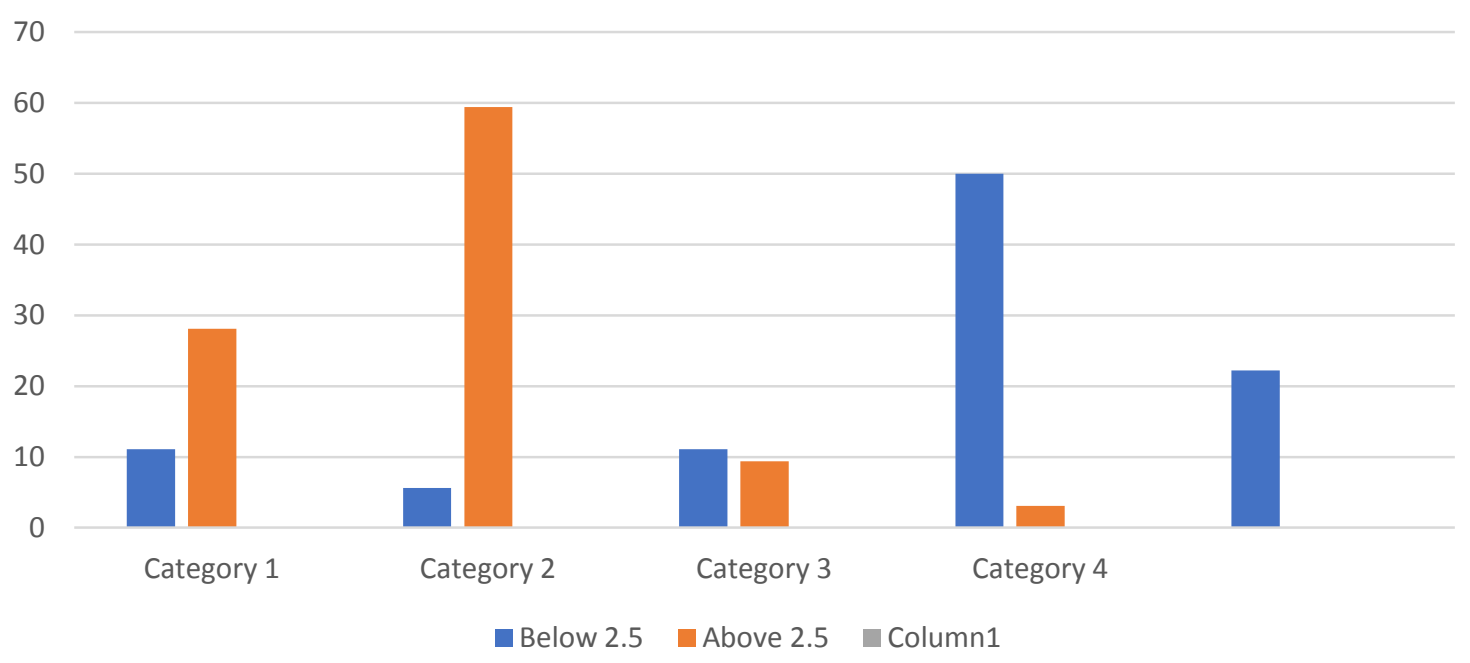


Comparison of Mental Status with Phosphorus Level

\begin{tabular}{|l|c|c|c|c|}
\hline $\begin{array}{l}\text { MENTAL } \\
\text { STATUS }\end{array}$ & $\begin{array}{c}\text { PHOSPHORUS } \\
<2.5 \mathrm{mEq} / \mathrm{L}\end{array}$ & $\begin{array}{c}\text { PHOSPHORUS } \\
2.5 \mathrm{mEq} / \mathrm{L}\end{array}$ & $\begin{array}{c}\text { PHOSPHORUS } \\
>2.5 \mathrm{mEq} / \mathrm{L}\end{array}$ & $\begin{array}{c}\text { STATISTICAL } \\
\text { SIGNIFICANCE }\end{array}$ \\
\hline Drowsy & $10(55.6 \%)$ & $5(15.6 \%)$ & $15(30 \%)$ & $\begin{array}{c}\text { Significant } \\
\mathrm{p}<0.05\end{array}$ \\
\hline Normal & $8(44.4 \%)$ & $27(84.4 \%)$ & $35(70 \%)$ & $\begin{array}{c}\text { Significant } \\
\mathrm{p}<0.05\end{array}$ \\
\hline
\end{tabular}

There is a statistically significant association between mental status and serum phosphorus level at the time of admission of DKA patients.

It is proven by Chi Square test.

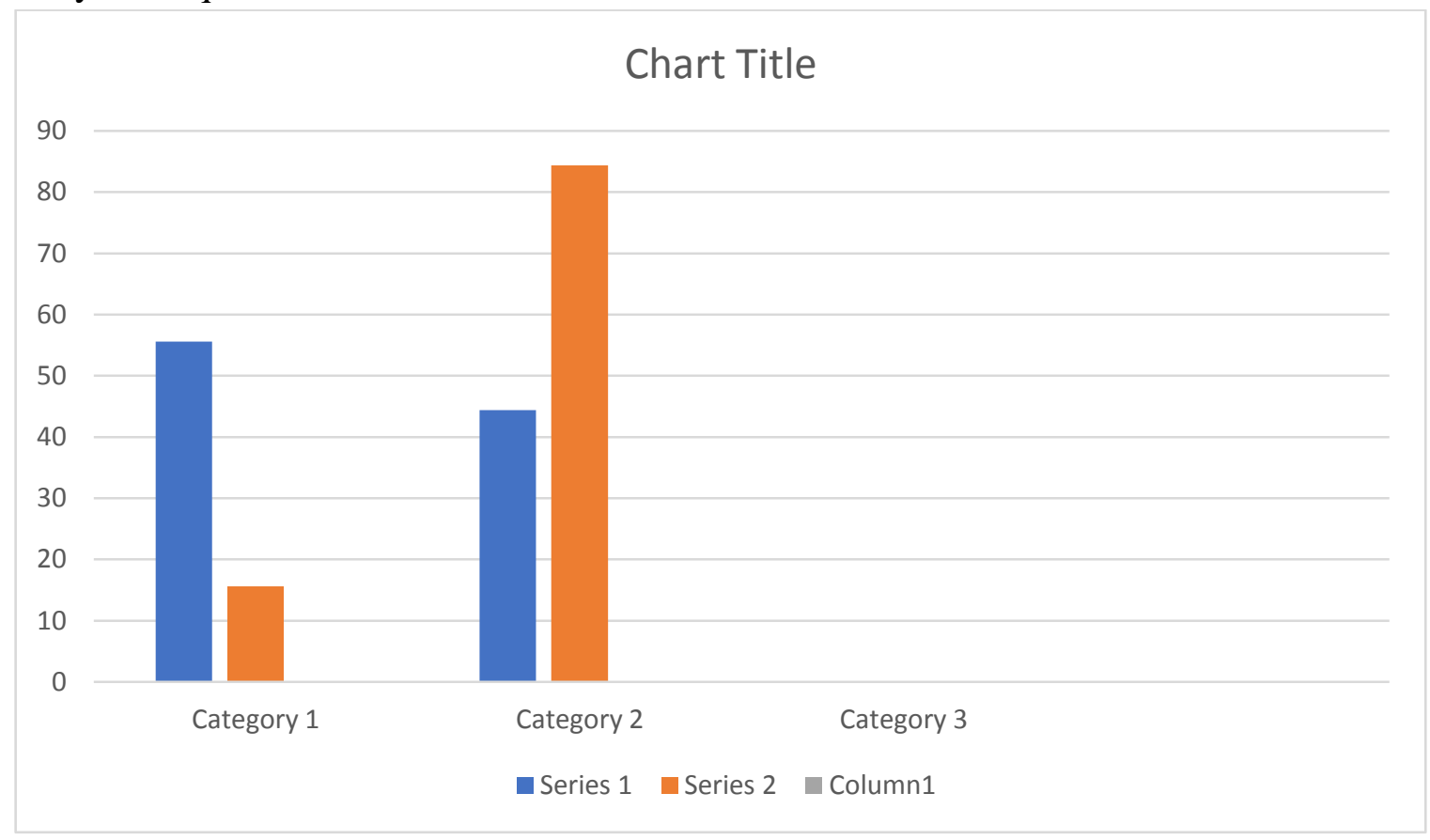

\section{Discussion}

Phosphorus is a widely distributed element in the human body. The normal value for phosphorus is 2.5 to $4.5 \mathrm{mg} / \mathrm{dL}^{[3]}$. It is present in both organic and inorganic forms but only serum inorganic phosphate is measured. Inorganic phosphorus in the form of hydroxy apatite in bone plays an important role in the structural support of the body and also provides phosphate for intracellular and extracellular fluid ${ }^{[4]}$.

Insulin enhances the reduction in serum phosphorus in both diabetic and non-diabetic person. In severe uncontrolled hyperglycemia, high level of glucose results in low phosphorus levels due to intracellular phosphorylation of glucose and excessive loss in urine, resulting in diabetic osteopenia. Therefore normalization of blood glucose leads to an improved capacity of the kidney tubules to reabsorb inorganic phosphorus.
Phosphate levels should be monitored in diabetics treated with insulin ${ }^{[5]}$. When the level reaches $<1 \mathrm{mg} / \mathrm{dL}$, it needs replacement as potassium phosphate $^{[6]}$.

In our study, the admission blood sugar values were inversely proportional to the serum phosphorus levels.

The level of consciousness was in linear correlation with the serum phosphate. Most of the patients with hypophosphatemia were admitted in a drowsy state that was statistically significant when compared with patients with normal serum levels.

In our study, the duration of hospital stay was prolonged in patients with low serum phosphorus levels at admission due to more frequent occurrence of complications and poor glycemic control. 


\section{Conclusion}

In our study, higher the blood sugar value lower the serum phosphate value, and also low serum phosphate was associated with poor mental status at the time of admission and also associated with prolonged hospital stay. So low serum phosphorus level at admission is also a feature of poor outcome.

\section{Bibliography}

1. Derek Le Roith, Yehielzick. Recent advances in our understanding of insulin action and insulin resistance.

2. Tracy 1. setji, MD; Ann J.Brown, MD and Mark N.Feinglos, MD, CM. Gestational diabetes mellitus. Clinical diabetes. 2005; 23: $17-24$.

3. Henning TP, Cunningham TP. Biosensors for personal diabetes management. In Ramsay g, ed. Commercial biosensors. Newyork: John Wiley and Sons, 1998:346.

4. Williams, M.H. (1999) Nutrition for health, fitness and sport, $6^{\text {th }}$ edition. Boston: Mcgraw-Hill.

5. The expert committee on the diagnosis and classification of diabetes mellitus: report of the expert committee on the on the diagnosis and classification of diabetes mellitus. diabetes care 1997;20:11 831197.

6. David B Snacks, David E Goldstein, Noel K Maclaren, Jay M Macdonald, Maian Parrott. Guidelines and recommendation for laboratory analysis in the diagnosis and management of DM. clinical chemistry 2002;48:436-472. 